\title{
A Not-For-Profit Publisher's Perspective on Open Access
}

Martin Frank, Margaret Reich and Alice Ra’anan

American Physiological Society, Bethesda, Maryland 20814-3991

\section{Accepted and forthcoming in Serials Review, volume 30, no.4: Special Focus on Open Access: Issues, Ideas, and Impact doi: 10.1016/j.serrev.2004.09.002}

Corresponding Author:

Martin Frank, Ph.D.

Executive Director

American Physiological Society

9650 Rockville Pike

Bethesda, MD 20814-3991 U.S.A.

Tel: $\quad 301-634-7118$

Fax: 301-634-7242

Email: mfrank@the-aps.org

Margaret Reich

Director of Publications

American Physiological Society

9650 Rockville Pike

Bethesda, MD 20814-3991 U.S.A.

Tel: $\quad$ 301-634-7070

Fax: 301-634-7243

Email: mreich@the-aps.org

Alice Ra'anan

Public Affairs Officer

American Physiological Society

9650 Rockville Pike

Bethesda, MD 20814-3991 U.S.A.

Tel: $\quad 301-634-7105$

Fax: 301-634-7242

Email: araanan@the-aps.org 


\begin{abstract}
Recent legislative activity in the US House of Representatives and the UK House of Commons has added fuel to a debate over electronic access to the Scientific, Technical and Medical (STM) literature that was initiated in 1999 with the introduction of E-Biomed. On-going efforts to change the landscape of STM publishing involve moving it away from a subscription basis to an author-pays model. This article chronicles the swift evolution of electronic access to the scientific literature and asks whether the scholarly community will really be better off with government-mandated open access (OA) publishing.
\end{abstract}




\section{A Not-For-Profit Publisher's Perspective on Open Access}

The invitation to write about access control policies for Serials Review was welcome because it offered an opportunity to share the perspective of not-for-profit publishers with the library community. Although the American Physiological Society (APS) cannot speak for all not-forprofit publishers, we certainly can describe the ongoing APS experiment with author pays publishing through our newest journal, Physiological Genomics. This was also an opportunity to introduce the library community to the Washington DC Principles for Free Access to Science. ${ }^{1}$ This March 16, 2004, declaration, signed by 53 publishers, was an effort to have the voices of not-for-profit publishers heard above the drum beat for open access (OA) journal publishing.

In the meantime, however, recent actions taken by Committees of the US House of Representatives $^{2}$ and the UK House of Commons ${ }^{3}$ have changed the terms of the debate once again. Consequently, this article will provide a somewhat different perspective on the Open Access debate by offering a bird's-eye view as to where STM publishing has been and where it may be going. It will review the origins of the OA movement with a special focus on the factors that have ostensibly driven it - accessibility and cost. At the same time it will focus on the question of whether the OA initiative will truly leave us in a better place for the dissemination of STM content.

\section{A Decade of Progress}

To appreciate how far STM publishing has come in terms of providing electronic access to information, one should consider where we were just ten years ago when the era of online publication had not yet begun. Articles based upon NIH funded research were published in paper journals kept on the shelves of individual and institutional subscribers. The prototypical breast cancer patient who is often cited as the reason why we need Open Access would have had to go to a local library to obtain information about her condition. If she went to a public library she would most likely have been given a medical textbook. At a university library she would have fared somewhat better since she could browse through Index Medicus or the relevant shelved journals. She might even have been able to access Medline at the university library to find an abstract of a relevant article. Of course, she might not have been able to find the latest articles in Medline since titles, authors, and abstracts were keyed in manually, often months after publication. If the particular journal was in the library, she could photocopy it, but if not, she would have to ask the librarian to have it shipped from another library.

From today's vantage point of nearly universal Internet access, these constraints seem primitive and almost unimaginable, but in the early 1990s, we were only just starting to climb the technological mountain upon which we now stand. By the mid-1990s the Internet was becoming increasingly "user friendly" with the advent first of the Gopher and Lynx protocols and later the World Wide Web. As information technology evolved, journal publishers recognized its potential for information dissemination. Both not-for-profit and commercial publishers began looking at the risks and opportunities entailed in moving into the brave new world of electronic publication. In the mid-1990s personal computers were still relatively uncommon and much less information was available to the public over the Internet. Non-university users who did subscribe to online services such as Compuserve did so using dial-up modems. At a time when the Internet 
primarily served up unformatted text, it was a daring move to make the enormous investments in hardware and software to put information online.

\section{APS Goes Online}

In this uncertain environment, the APS participated in a number of experiments including the Red Sage Project and an ISI effort to bring the scientific literature to the Internet. APS launched its first online publication in 1993, posting the abstracts of accepted manuscripts on a Gopher server in an online journal called APStracts. As the technology rapidly evolved, APS recognized that abstracts alone were not enough so the Society began exploring ways to publish the full text of the journal articles online. The APS made its first foray into online posting of articles in 1994 when OCLC offered us a platform that was compatible with software that could accommodate the mathematical equations and scientific notation needed for reporting physiological research.

During the same period, a group out of Stanford University set up HighWire Press as another hardware and software platform for electronic publication. When OCLC ceased to support its software - one of the common hazards in the early days of electronic publication - the APS shifted its publications from OCLC to HighWire Press. In 1996, the APS put one of its thirteen print journals, the Journal of Applied Physiology, online. It was a time when there was much for publishers both to hope for and to fear from the online world. Would publishers be able to recover the cost of their investment in electronic publishing? Would subscribers cancel their print subscriptions if journals went online? How could publishers keep their journals going and prepare for the inevitable evolution of the technology? These were still unknowns, but response to online publication of the Journal of Applied Physiology was so favorable that the Society went forward and moved all thirteen APS journals online. It was clear that "if we were not online, we did not exist." Recognizing that the Internet was the wave of the future, APS also worked with ScholarOne to develop a Web-based system for the submission and peer review of manuscripts which the Society calls “APS Central”.

\section{Government-run Scientific Publishing}

The APS and other STM publishers were scarcely the only ones who recognized the benefits that the Internet might offer for the dissemination of scientific information. In 1999, then-NIH Director Harold Varmus, along with Patrick Brown of Stanford University and David Lipman of the National Library of Medicine's National Center for Biotechnology Information, unveiled a proposal for E-Biomed. It was described as "an ambitious Web-based publishing venture that could radically change the way biology papers are disseminated." 4 E-Biomed was intended to be a centralized repository where all biomedical journals would deposit their content; however, this visionary plan met with a mixed response. Even OA supporters such as Tony Delamothe of the British Medical Journal said that he sensed some "messianism" in this scheme for reorganizing scientific publishing. ${ }^{5}$ While E-Biomed was not adopted, the NLM subsequently created PubMed Central to serve as a repository for journal articles. Because publishers were initially required to make their content free immediately, most were unwilling to participate in the venture. 
In 2003 a number of prominent OA advocates in the US launched a publishing venture called the Public Library of Science (PLoS). As originally envisioned, the PLoS family of journals would provide immediate, unrestricted free access to scientific content financed by a $\$ 1,500$ publication fee for accepted manuscripts. The scope of their ambitions is evident in the comments of Michael Eisen, one of the co-founders of PLoS, who was quoted at around the same time as saying, "We are not just another Nature, Science or Cell. We are morally superior and what we are doing is better for the future of science." 6

Eisen's comments as well as those of other PLoS founders along with their actions over the past several years suggest an unwillingness to accept any view but their own. The DC Principles for Free Access grew out of frustration because the legitimate concerns of the not-for-profit publishers were not being heard. "More than trying to improve electronic dissemination of research, the founding fathers of PLoS have launched a full-bore, expensive, and high-powered assault on STM publishers in the guise of a grass-roots movement."7 They claim they are not attacking other publishers, but their actions speak louder than their words.

Although OA advocates say that change is needed to improve the accessibility of governmentfunded science, they fail to acknowledge that STM content is far more accessible today than it has ever been. Many publishers make the full text of their journals freely available within months of publication, but they decide how rapidly to lift access controls based upon how they recover their costs. The fifty-three DC Principles publishers alone have made more than 800,000 articles available online with nearly 500,000 available for free. ${ }^{8}$ In addition, they are working with other not-for-profit publishers to make additional articles available by linking references between journals.

OA advocates complain about a lack of access to the scientific literature for scientists in developing countries. However, many publishers sent complimentary copies of print journals overseas prior to the Internet and currently make the online content freely available through groups such as HINARI (Health InterNetwork Access to Research Initiative, http://www.healthinternetwork.org/) and AGORA (Access to Global Online Research in Agriculture, http://www.aginternetwork.org/en/) that coordinate the distribution of online content to low-income nations.

As for individuals who do not have access to an institutional library, the abstracts of all articles published online by publishers in the DC Principles coalition are freely available through their journal Web sites or PubMed. The full text of articles still under subscription access control can be purchased online, often for less than $\$ 10$. In the case of patients seeking treatment information, most not-for-profit publishers will provide an article without charge in instances of compassionate need. Thus, the publishers participating in the DC Principles coalition are already making content freely available on an expedited basis to those who cannot afford to pay and to everyone else under a timetable that enables them to sustain their operations.

\section{Free is Still Not Free}

Accessibility is not a compelling reason to overturn STM publishing, but OA advocates also complain that subscription prices are too high and an author-pays model would be more cost 
effective. The high cost of publishing is a reality, but during the period from 1988 to 1998, subscription prices increased far more sharply for commercial biomedical titles than for not-forprofit titles. ${ }^{9}$ This problem has been further exacerbated by the so-called "Big Deals" that commercial publishers have negotiated with libraries, which sharply reduce the funds available for the purchase of other journals.

While institutional subscription prices of not-for-profit journals have increased along with those of commercial journals, the former provide a better cost-per-page value than the latter (Table 1) as well as on a cost-per-citation basis. ${ }^{10}$ Moreover, not-for-profit publishers recognize the need to hold down subscription prices. Bringing this message to the library community and the public was another important reason why the DC Principles coalition was formed.

PLoS proponents have repeatedly told the public and the scientific community that it should cost no more than $\$ 1,500$ to publish an article online in a rigorously reviewed, high stature journal. A white paper posted on the PLoS website offers a breakdown showing that the cost of publishing an article in PLoS Biology is $\$ 1,069,{ }^{11}$ but the expenses listed only cover manuscript processing and production. Other equally essential publishing costs such as marketing, Web hosting, editorial staff, and overhead are omitted. An APS cost analysis for its journal program shows that for the 4,000 articles the Society publishes annually, the comparable cost per article is $\$ 827.72$. As noted in Table 2, the difference is predominantly attributable to the differences in manuscript acceptance rate for the two journal programs. However, when the APS includes all the costs associated with the publication of an article, the total average cost of each article increases to \$2,635, which includes editorial staffing, Web hosting, marketing, overhead, etc. Another example is provided by the American Society for Clinical Investigation, a signer of the DC Principles, which has shown that the cost per article for its highly selective Journal of Clinical Investigation is approximately $\$ 6,000 .^{12}$

The need to supplement its $\$ 1,500$ submission fee may explain why PLoS and other OA journals have been seeking new revenue sources. PLoS started with a $\$ 9$ million grant from the Gordon and Betty Moore Foundation. However, at the July 20, 2004, E-Journal Summit, held at the National Academy of Sciences PLoS Executive Director Vivian Siegel conceded that relying upon a $\$ 1,500$ per article author submission fee was not a sustainable business model. That is the reason why PLoS initiated a membership program that Siegel described as a way to spread publication costs across multiple sources: author fees and institutional membership fees that range from $\$ 2,000$ to $\$ 100,000 .^{13}$ This could be seen as a mirror image of the model used by most not-for-profit journals, which hold down the costs of institutional subscriptions by asking authors to pay page charges.

\section{Business Models: Variations on a Theme}

Enthusiasm for the concept of OA publishing model has encouraged a number of publishers/journals to experiment with this business model. While BioMed Central's (BMC) OA program predates the launch of PLoS, having begun in May 2000, its founding was greatly influenced by Varmus' early advocacy of E-Biomed. BMC journal authors are charged fees ranging from $\$ 525$ to $\$ 1,500$ depending upon the journal. ${ }^{14}$ Alternatively, institutions can purchase a "membership" that allows their authors to publish articles without paying the fee; 
however, the membership fee is to be recalculated annually based on the number of articles that authors from that institution published during the previous year. Since libraries have been paying the membership fees, this means that librarians will now face the challenge of budgeting for a variable expense that could increase.

The APS is also experimenting with an author pays model for our journal Physiological Genomics. Authors have the option to pay $\$ 1,500$ to permit the immediate release of their content. The alternative is to pay no page charges, and the article will be made freely available after 12 months. To date, only $10 \%$ of the authors have accepted the Society's invitation to pay the fee to provide immediate access to their articles. Meanwhile, the institutional online subscription price for Physiological Genomics is only \$205.

Oxford University Press has recently announced that it will try an OA model in 2005 with Nucleic Acids Research. ${ }^{15}$ Under the 2004 fee structure, an author must pay \$208 for each page in excess of nine pages, and the online institutional subscription price is $\$ 2459$. When NAR becomes OA in 2005, authors will be charged $\$ 500$ per accepted paper if their institutions are $N A R$ members and $\$ 1,500$ if they are non-members. Institutional membership in NAR will cost $\$ 2,459$, which is the same as the 2004 online subscription price.

Commercial publishers are also responding to the OA movement's call for immediate access to content. Elsevier allows for the posting of the author's final version of the manuscript on a personal or institutional Web site, provided there is a link to the journal's home page or the article's DOI and a complete citation. Springer has announced the launch of Springer Open Choice, a program that allows journal authors to pay a basic fee to have their articles made available immediately to the public. ${ }^{16}$ The Springer Open Choice fee is currently set at $\$ 3,000$. While Springer pledges to reduce subscription rates as OA authors sign up, until they do, Springer retains its subscription fees, and makes no mention of institutional memberships.

\section{Will Libraries Really Benefit?}

Many institutions support OA publishing because they see it as a solution to the problem of diminishing library budgets and the increasing costs of journals, primarily those of commercial publishers. Not-for-profit journals are not generally seen as the source of the cost increase problem. During a press briefing about the DC Principles, University of Virginia Librarian Karin Wittenborg noted that "the costs of [society] journals are predictable and reasonable and they reinvest in the advancement of research and scholarship." Wittenborg called society publishers "the 'good guys' of scholarly publishing.",17

Wittenborg raised an important question about OA journals when she asked, "Will low costs today be low costs tomorrow?” Other librarians are also asking whether author-pays publishing will in fact prove cost effective for the institution. Table 3 compares the costs associated with publishing in different kinds of journals. It suggests that if the institutional library covers a portion of author fees, OA journals may prove more costly than traditional subscription-based journals. Furthermore, these costs may fluctuate significantly. For example, BioMed Central has set the first year membership fee for a large institution (between 5,001 and 10,000 faculty and postgraduate students in biology and medicine) at $\$ 8,060 .{ }^{18}$ Membership allows the institution's faculty to publish for free in over 100 BMC journals. However, in the second year, the 
membership fee will be determined by multiplying $\$ 525$ times the number of articles the faculty published in BMC journals during the previous year. If the APS operated under this structure, a large research university, whose faculty and postdocs published 109 articles in our 13 journals in 2003 , would have to pay $\$ 57,225$ (109 times $\$ 525$ ) for its second year of institutional membership. In comparison, institutional subscriptions to all 13 APS journals costs only $\$ 5,205$ and provides everyone at the large research university with free and immediate access to all our journals.

Traditional journal publishers have frequently been lambasted for using subscriptions as ransom for access to the scientific literature. But is it any less objectionable for OA publishers to link the fees they charge authors to institutional "memberships"? There will no doubt be great pressure from researchers for institutions to become members both to support OA publishing and to reduce their own authorship costs. However, when it is time to prepare their budgets, libraries may find that they have gotten rid of one serials crisis only to face an even bigger crisis due to escalating and unpredictable membership fees. The promise that OA publishing will reduce the cost of access to information has been one of its primary justifications, but not-for-profit publishers have already demonstrated their ability to deliver on this promise.

\section{Deus ex machina?}

While the APS provides free access to research content 12 months after publication, it is a decision that had been made be the Society as a publisher. Efforts to mandate a publishing model that requires the free availability of content, whether after 12 months, 6 months, or immediately, will likely put undue stress on a system that has successfully evolved over the last decade as content has migrated from paper to the Internet. It will force some publishers to make content available at a time that is inconsistent with their publication model. Through the current evolutionary process the public has been provided with access to more content than ever before. The publishers were the ones who responded to the cry for increased accessibility by putting content on the Internet and reducing their access control periods from years to months.

Nevertheless, on July 14, 2004, the US House Appropriations Committee issued a report along with its FY 2005 funding bill for the Departments of Labor, HHS and Education that would "require[e] that a complete electronic copy of any manuscript reporting work supported by NIH grants or contracts be provided to PMC [PubMed Central] upon acceptance of the manuscript for publication in any scientific journal listed in the NLM's [National Library of Medicine] PubMed directory.” The committee further instructed the NLM to "commence making these reports, together with supplemental materials, freely and continuously available no later than six months after publication, or immediately in cases in which some or all of the publication costs are paid with NIH grant funds." ${ }^{19}$ Although report language is advisory rather than mandatory, this is the kind of instruction that agencies ignore at their peril.

The following week on July 20, 2004 the UK House of Commons Science and Technology Committee issued a report based upon its investigation of scientific publishing practices. The House of Commons panel recommended that government-funded researchers be required to deposit a copy of their scientific papers in a set of interlinked electronic archives. Its report calls for the UK government to "fund the establishment of an interlinked network of institutional 
repositories on which all research articles originating in the UK should be deposited and can be read for free.” It further recommends that non-governmental research councils require their funded researchers to deposit copies of their articles in these archives. ${ }^{20}$

There are, of course, a number of specific reasons why these proposals will fail to provide satisfactory answers to the problem of providing cost-effective access to the scientific literature. But above and beyond those problems, the fact remains that a government-imposed solution could have the effect of hampering the ability of this complex and diverse industry to respond to the on-going revolution in information technology.

Some publishers are experimenting with elements of the US House of Representatives and the UK House of Commons recommendations, namely making accepted manuscripts available free immediately while controlling access to the version of the article containing the added value of redaction, copy-editing and formatting. However, that practice may not be suitable for every type of publication. In addition, placing manuscripts in pre-print archives could lead to confusion because there will be multiple published versions of a single article residing on different sites. Clinical journals will have to speak for themselves about the implications of providing immediate public access to unedited manuscripts.

Furthermore, requiring free access on a government-mandated schedule will cause some journals to lose the subscription revenue they need to sustain their operations. If this forces them out of business, it could cause irrevocable harm to the communities of scholars that rely upon them. The DC Principles endorses the notion that publishers should be allowed to establish access policies in accordance with their subscription base and other financial considerations.

Another troubling element in the US committee language is the requirement that PubMed Central become the sole national repository of accepted manuscripts. In contrast, the UK committee recommended that its government support a network of interlinked repositories. The US language would seem to be an outgrowth of the original vision behind E-Biomed. But there are other ways to ensure the accessibility of science without creating a single governmentrun repository. Many of the signers of the DC Principles utilize the services of HighWire Press for online publishing. HighWire has created a robust and stable platform that currently houses nearly 400 journals and supports over 1.8 million articles, including 750,000 that are freely available. HighWire has also developed a number of archival solutions designed to ensure the integrity of its collection and has created a web portal called the HW Library of the Sciences \& Medicine ${ }^{21}$ that allows for highly sophisticated searching across the content of all the HW journals. The HighWire Library of the Sciences \& Medicine makes it possible to search 14 million articles in over 4,500 Medline journals. This portal, which was developed by the HighWire collective, currently exceeds PubMed Central in its utility.

\section{A Costly Solution in Search of a Problem}

In 1999, PLoS cofounder Patrick Brown suggested that one reason for E-Biomed was to provide a searchable site for gene expression data. Along with Richard Young of the Whitehead Institute for Biomedical Research, they suggested that a centralized mechanism be created so that dynamic computer displays of microarrays could be visualized, thus enabling researchers to 
make sense of this information. ${ }^{22}$ PLoS founders Brown and Eisen have similarly said that a centralized repository of NIH funded content is needed for effective searching and information retrieval, but this is no longer the case with the latest generation of search engines. Journal of Biological Chemistry editor Robert Simoni of Stanford University has shown that Google now provides the largest number of reader referrals to the $J B C$ (Table 4). Long-time OA advocate Stevan Harnad says that the real issues should be whether articles' full text is OAI-compliant and whether the articles are openly accessible anywhere on the web. As far as Harnad is concerned, where the article is deposited is irrelevant. ${ }^{23}$

In addition, establishing a centralized archive for NIH research has cost implications and will create a financial burden that has been estimated to be $\$ 50$ million. A sum of this magnitude could be better spent to further the NIH's mission of supporting health research. ${ }^{24}$ Nor will a centralized repository provide much help to individual patients, most of whom appropriately rely upon the expertise provided by voluntary health agencies to assess the significance of new scientific discoveries. Rather than create an expensive and superfluous government repository, why not invest in developing search tools to maximize the functionality of PubMed with links out to publishers' content on their own sites?

Questions about optimizing access to the STM literature will be with us for many years to come. Publishers will keep looking for ways to make the content more readily available both to subscribers and to other interested persons. Legislative intervention is disruptive and unnecessary, but one can only hope that these and other concerns of not-for-profit publishers will be heard in the midst of the well-orchestrated clamor for Open Access.

\section{ENDNOTE:}

There have been further developments since this article was written. On September 3, 2004, the NIH published a proposal for public comment in the NIH Guide to Grants and Contracts. Rather than requiring grantees to deposit their manuscripts in PubMed Central, the NIH plans to offer this as a means to fulfill their reporting requirement. In addition, all mss would be made publicly accessible after 6 months, with no requirement to grant immediate free access if grant funds were used to pay publication costs. Despite these marginal changes, our stated concerns remain. 


\section{NOTES}

1. Washington DC Principles for Free Access to Science http://www.dcprinciples.org/statement.htm (accessed March 16, 2004).

2. $\quad$ Andrea L. Foster, “Today’s News: House Committee Tells NIH to Post Research Results Online and Make Them Free.” The Chronicle of Higher Education, Monday, July 19, 2004.

3. Scientific Publications: Free for All? Science and Technology Committee $10^{\text {th }}$ Report. House of Commons (UK) Session 2003-2004 (HC 399-1)

4. $\quad$ Eliot Marshall, "NIH Weighs Bold Plan for Online Preprint Publishing.” Science 283 (1999 March 12): 1610-1611.

5. $\quad$ Eliot Marshall, "NIH Weighs Bold Plan for Online Preprint Publishing.” Science 283 (1999 March 12): 1610-1611.

6. $\quad$ Susan R. Owens, “Revolution or Evolution?” EMBO Reports 4(8):741-743, 2003.

7. Margaret Reich, "Peace, Love and PLoS.” The Physiologist 46 (4): 137, 139-141, 2003.

8. $\quad$ Presentation of Martin Frank, Ph.D., DC Principles Press Briefing http://www.dcprinciples.org/presentations/frank.htm (accessed March 16, 2004).

9. Mark J. McCabe, “The Impact of Publisher Mergers on Journal Prices: An Update.” ARL Bimonthly Report 207 (December 1999): http://www.arl.org/newsltr/207/jrnlprices.html (accessed August 9, 2004).

10. Carl T. Bergstrom and Theodore C. Bergstrom, "The Costs and Benefits of Library Site Licenses to Academic Journals.” Proc. Natl. Acad. Sci. 101:897-902, 2004.

11. Publishing Open-Access Journals. A Brief Overview from the Public Library of Science February 2004. page 12. www.plos.org/downloads/oa_whitepaper.pdf

12. John B. Hawley, Is Free Affordable? Nature Web Focus: Access to the literature: the debate continues. http://www.nature.com/nature/focus/accessdebate/14.html (accessed July 27, 2004).

13. PLoS Institutional Membership. Public Library of Science. http://www.publiclibraryofscience.org/support/instmembership.html (accessed August 30, 2004).

14. Frequently asked questions about BioMed Central's article-processing charges. BioMed Central. http://www.biomedcentral.com/info/authors/apcfaq (accessed August 30, 2004).

15. Nucleic Acids Research. NAR's Open Access Experiment. http://www3.oup.co.uk/nar/special/14/default.html (accessed August 30, 2004).

16. Springer Open Choice ${ }^{\mathrm{TM}}$ http://www.springeronline.com/sgw/cda/frontpage/0,10735,1-40359-0-0-0,00.html (accessed August 30, 2004)

17. Presentation by Karin Wittenborg. DC Principles Press Briefing http://www.dcprinciples.org/presentations/wittenborg.htm (accessed March 16, 2004).

18. BioMed Central Institutional Membership. BioMed Central. http://www.biomedcentral.com/info/libraries/instmembership (accessed August 30, 2004). 
19. Andrea L. Foster, “Today’s News: House Committee Tells NIH to Post Research Results Online and Make Them Free.” The Chronicle of Higher Education, Monday, July 19, 2004.

20. Scientific Publications: Free for All? Science and Technology Committee $10^{\text {th }}$ Report. House of Commons (UK) Session 2003-2004 (HC 399-1)

21. Public Library of the Sciences and Medicine. HighWire Portal, www.highwire.org (accessed August 9, 2004).

22. Eliot Marshall, "NIH Weighs Bold Plan for Online Preprint Publishing.” Science 283 (1999 March 12): 1610-1611.

23. Stevan Harnad, e-mail message to American-Scientist-Open-Access-Forum Mandating OA around the corner? July 25, 2004. http://listserver.sigmaxi.org/sc/wa.exe?A2=ind04\&L=american-scientist-open-accessforum $\& D=0 \& F=\mid \& P=65612$

24. Jocelyn Kaiser, “Seeking Advice on 'Open Access,' NIH Gets an Earful.” Science 305:764, 2004 
Table 1 - Mean institutional price (\$) per page for journals in six scientific fields

\begin{tabular}{|l|r|r|}
\hline \multicolumn{1}{|c|}{ FIELD } & For Profit & Not-for-Profit \\
\hline Ecology & 1.01 & 0.19 \\
\hline Economics & 0.83 & 0.17 \\
\hline Atmospheric Science & 0.95 & 0.15 \\
\hline Mathematics & 0.70 & 0.27 \\
\hline Neuroscience & 0.89 & 0.10 \\
\hline Physics & 0.63 & 0.19 \\
\hline
\end{tabular}

Source: Carl T. Bergstrom and Theodore C. Bergstrom, “The Costs and Benefits of Library Site Licenses to Academic Journals.” Proc. Natl. Acad. Sci. 101:897-902, 2004. 
Table 2 - Analysis of Article Cost Using the PLoS Cost Analysis Model

\begin{tabular}{lrr} 
& PLoS & \multicolumn{1}{c}{ APS } \\
Peer Review, per accepted mss* & 200.00 & 40.00 \\
Copyediting and fig. editing & 380.00 & 315.85 \\
Composition & 366.25 & 420.73 \\
Electronic file prep (not inc. hosting) & 111.00 & 49.29 \\
Cross ref deposits & 12.50 & 1.85 \\
Total & $\mathbf{1 , 0 6 9 . 7 5}$ & $\mathbf{8 2 7 . 7 2}$ \\
Total based on actual costs, inc. all & $\mathbf{2}$ & $\mathbf{2 , 6 3 5 . 0 0}$ \\
else & & \\
(PLoS model does not inc. ed staff, & & \\
overhead, marketing, Internet hosting) & & \\
& & \\
*Cost per submitted article is \$20 for & & \\
PLoS and APS, but PLoS assumes a & \\
10\% acceptance rate, and APS assumes & \\
a 50\% acceptance rate &
\end{tabular}


Table 3 - Cost comparison across several different journals incorporating author pays and subscription models.

\begin{tabular}{|c|c|c|c|c|c|}
\hline Journal & $\begin{array}{l}\text { Author } \\
\text { Fees }\end{array}$ & $\begin{array}{l}\text { Cost for } 10 \\
\text { articles/10 } \\
\text { pages each }\end{array}$ & $\begin{array}{l}\text { Online } \\
\text { Subscription } \\
\text { Fee }\end{array}$ & $\begin{array}{l}\text { Institutional } \\
\text { Membership } \\
\text { Fee }\end{array}$ & $\begin{array}{l}\text { Total } \\
\text { Cost to } \\
\text { Institution }\end{array}$ \\
\hline $\begin{array}{l}\text { APS - Physiological } \\
\text { Genomics }\end{array}$ & \$0/page & $\$ 0$ & $\$ 205$ & $\$ 0$ & $\$ 205$ \\
\hline $\begin{array}{l}\text { APS - Physiological } \\
\text { Genomics }^{*}\end{array}$ & $\$ 1,500$ & $\$ 15,000$ & $\$ 205$ & $\$ 0$ & $\$ 15,205$ \\
\hline $\begin{array}{l}\text { APS - Journal of } \\
\text { Neurophysiology }\end{array}$ & \$70/page & $\$ 7,000$ & $\$ 1,030$ & $\$ 0$ & $\$ 8,030$ \\
\hline PLoS Biology ${ }^{*}$ & $\$ 1,500$ & $\$ 15,000$ & $\$ 0$ & $\$ 0$ & $\$ 15,000$ \\
\hline PLoS Biology ${ }^{*}$ & $\$ 1,350$ & $\$ 13,500$ & $\$ 0$ & $\$ 2,000$ & $\$ 15,500$ \\
\hline PLoS Biology ${ }^{*}$ & $\$ 900$ & $\$ 9,000$ & $\$ 0$ & $\$ 25,000$ & $\$ 34,000$ \\
\hline PLoS Biology ${ }^{*}$ & $\$ 375$ & $\$ 3,750$ & $\$ 0$ & $\$ 100,000$ & $\$ 103,750$ \\
\hline $\begin{array}{l}\text { OUP - Nucleic Acid } \\
\text { Research (2004) }\end{array}$ & $\$ 208$ & $\$ 2,080$ & $\$ 2,459$ & $\$ 0$ & $\$ 4,539$ \\
\hline $\begin{array}{l}\text { OUP - Nucleic Acid } \\
\text { Research (2005) }\end{array}$ & $\$ 500$ & $\$ 5,500^{+}$ & $\$ 0$ & $\$ 2,459$ & $\$ 7,959$ \\
\hline $\begin{array}{l}\text { OUP - Nucleic Acid } \\
\text { Research (2005) }\end{array}$ & $\$ 1,500$ & $\$ 15,500^{+}$ & $\$ 0$ & $\$ 0$ & $\$ 15,500$ \\
\hline $\begin{array}{l}\text { BioMed Central - } \\
\text { Journal of Biology }\end{array}$ & $\$ 1,500$ & $\$ 15,000$ & $\$ 0$ & $\$ 0$ & $\$ 15,000$ \\
\hline $\begin{array}{l}\text { BioMed Central - } \\
\text { Journal of Biology }\end{array}$ & $\$ 0$ & $\$ 0$ & $\$ 0$ & $\begin{array}{l}\$ 5,250 \text { (based } \\
\text { on } 10 \\
\text { submissions) }\end{array}$ & $\$ 5,250$ \\
\hline
\end{tabular}

\footnotetext{
*Immediate Free Access

\#after 12 months

${ }^{+}$OUP charges $\$ 50$ for all pages over 9

Note - The multiple lines for PLoS and BMC journals shows the effect of different membership levels on total institutional cost.
} 
TABLE 4 - Referring Site Report for the Journal of Biological Chemistry (1 week analysis)

\begin{tabular}{|c|c|}
\hline April 2003 & April 2004 \\
\hline 792431 - http://www.jbc.org & 1328544 - http://www.jbc.org \\
\hline 31471 - http://intl.jbc.org & 31207 - http://intl.jbc.org \\
\hline 26946 - http://www.ncbi.nlm.nih.gov & 30235 - http://www.google.com \\
\hline 4719 - http://highwire.stanford.edu & 26698 - http://www.ncbi.nlm.nih.gov \\
\hline 3783 - http://www.google.com & 16300 - http://search.yahoo.com \\
\hline 1740 - http://www.pnas.org & 5717 - http://search.msn.com \\
\hline 1033 - http://www.sciencemag.org & 5122 - http://highwire.stanford.edu \\
\hline
\end{tabular}

Source: Robert D. Simoni. American Society for Biochemistry and Molecular Biology Public Affairs Symposium, ASBMB Annual Meeting. Boston, MA June 15, 2004 